\title{
When Photographs Speak, To Whom Do They Talk? The Origins and Audience of SSSR na stroike (USSR in Construction) $^{1}$
}

\section{Erika Wolf}

\begin{abstract}
The rapid growth of socialist construction in the Soviet Union is evoking great interest in foreign countries. The State Publishing House of the RSFSR has therefore conceived the idea to publish a special illustrated magazine The USSR in Construction, reflecting the colossal construction now taking place in the Soviet Union.

The State Publishing House has chosen the photo as a method to illustrate socialist construction, for the photo speaks much more convincingly in many cases than even the most brilliantly written article.

The USSR in Construction will be published monthly in special English, German, French and Russian editions.

The editorial board of The USSR in Construction hopes that this magazine will meet merited attention on the part of those interested in the progress of socialist construction in the USSR.
\end{abstract}

"From the Editors," USSR in Construction, 1930, no. 1.

It has often been assumed that the lavishly printed Soviet photographic propaganda magazine SSSR na stroike (USSR in Construction, 1930-1941, 1949) was intended primarily for a foreign audience and that its chief function was to cultivate support abroad for the Soviet Union. ${ }^{2}$ Published in Russian, English, German, and French editions, the purpose of this magazine was to illustrate visually the enormous changes taking place in the Soviet Union during the period of "socialist construction." With the renewal of Western interest in the Soviet avant-garde since the 1960s, SSSR na stroike has gained notoriety due to the involvement in its production of significant Soviet vanguard artists, photographers, and writers, including El Lissitzky, Aleksandr Rodchenko, and Varvara Stepanova. In the wake of the October Revolution, these Constructivist artists rejected traditional artistic creation in favor of engaged utilitarian practice. The work of these individuals on prominent Soviet propaganda after the purported forced dissolution of the avant-garde project by the Central Committee's Decree on the Reconstruction of Literary and Artistic Organizations in April 1932 could be easily explained by the fact that these images were intended for a foreign audience and were not for domestic consumption.

Visual and archival materials indicate that the question of SSSR na stroike's audience and intended message is not so simple. The complexity of the magazine's audience and how it "spoke" are suggested by several 


\section{Left History 6.2}

contemporary representations of the magazine: a photograph that purportedly documents the distribution of periodicals, including SSSR na stroike, at a Siberian collective farm in 1932 (fig. 1); a photograph of George Bernard Shaw examining the English edition, USSR in Construction, in November of 1933 (fig. 2); and copies of SSSR na stroike lying at a table, among a variety of other Soviet publications, scattered before the standing figure of Stalin in an oil painting by Isaak Brodskii from 1937 (fig. 3). These three images alone vastly complicate the question of the magazine's audience and what its representations meant to readers. While the definition of readership and reception of most any publication is a delicate affair, this task is further exacerbated by the disappearance of the archives of the magazine. While the prominent association of the venerated writer Maksim Gor'kii with SSSR na stroike suggests that these documents were not destroyed, the purge of almost the entire editorial board, including editor-in-chief Georgii (Iurii) L. Piatakov and E.S. Ezhova (wife of the Nikolai Ezhov, head of the People's Commissariat of Internal Affairs, the Soviet secret police force which carried out the Terror), most likely led to the secreting of these documents. ${ }^{3}$ As a central defendant in the Trial of the Anti-Soviet Trotskyite Center, Piatakov was executed in 1937 and was not rehabilitated until $1988 .{ }^{4}$ Drawing upon available published and archival sources, I will trace the origins of the magazine, demonstrate the shifting nature of its ideal audience, and reconsider the nature and significance of avant-garde contributions to this exemplary Stalinist publication. Contrary to the usual assumption, I will present evidence that the contribution of

prominent Constructivists to the magazine coincided with the emergence of the new Stalinist elite as the primary ideal readership of SSSR na stroike. ${ }^{5}$

\section{ORIGINS}

SSSR na stroike was initially conceived as an illustrated supplement to Nashi dostizheniia ("Our Achievements," 1929-1937), a popular literary magazine founded by Maksim Gor'kii and published by Gosizdat, the State Publishing House of the Soviet Union. Nashi dostizheniia sought to show Soviet workers and farmers the successful results of their work in all areas of construction throughout the country. Gor'kii's programmatic editorial for the first issue, "About the Little People and Their Great Work," includes an analogy to coral polyps, tiny blind creatures that unite together to build enormous reefs, fortresses which are able to smash iron ships. ${ }^{6}$ By popularizing diverse achievements of socialist construction among a mass audience, Nashi dostizheniia sought to stimulate the formation of a socialist consciousness among Soviet workers and peasants, to enable them to see their work, however minor it might seem, as part of a larger project that would build a socialist state. In the premiere editorial Gor'kii identified the factual essay as the primary vehicle for accomplishing this and documentary film that records the successes of everyday life is set forth as a model; both the ocherk and 


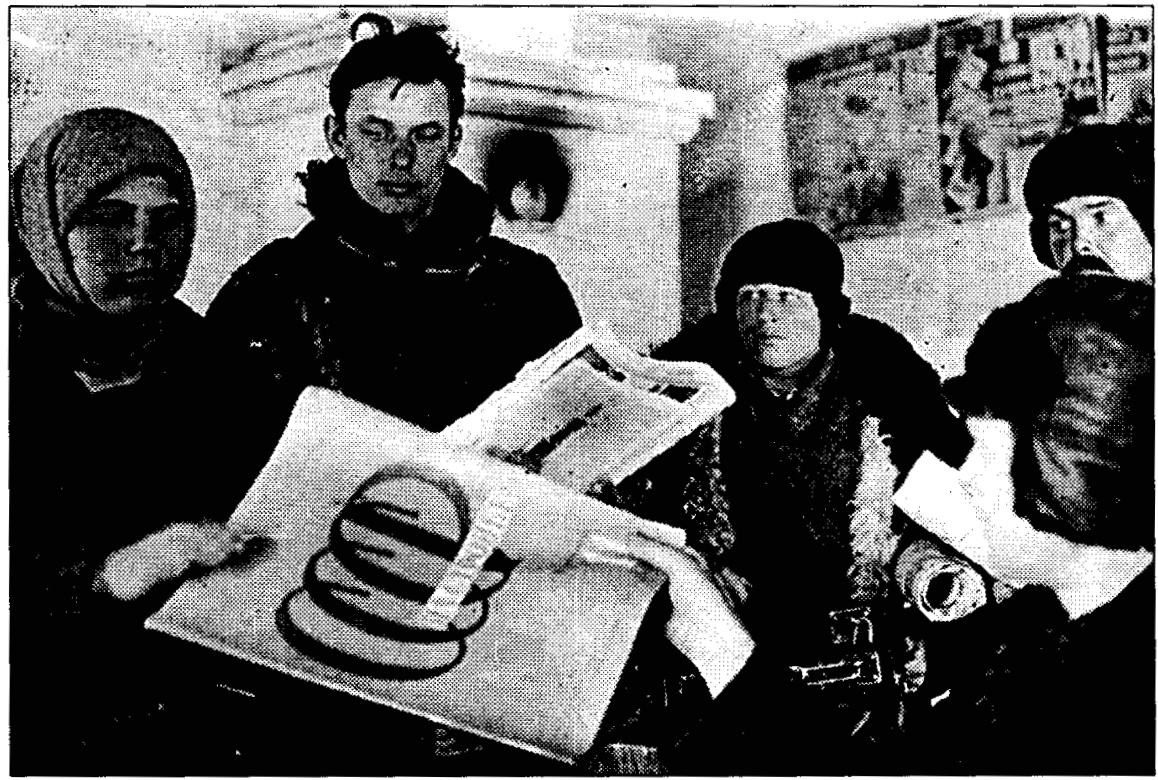

Figure 1: Distribution of Soviet Periodicals at a Siberian Collective Farm, 1932 International Historical Press Photo Collection, Stockholm

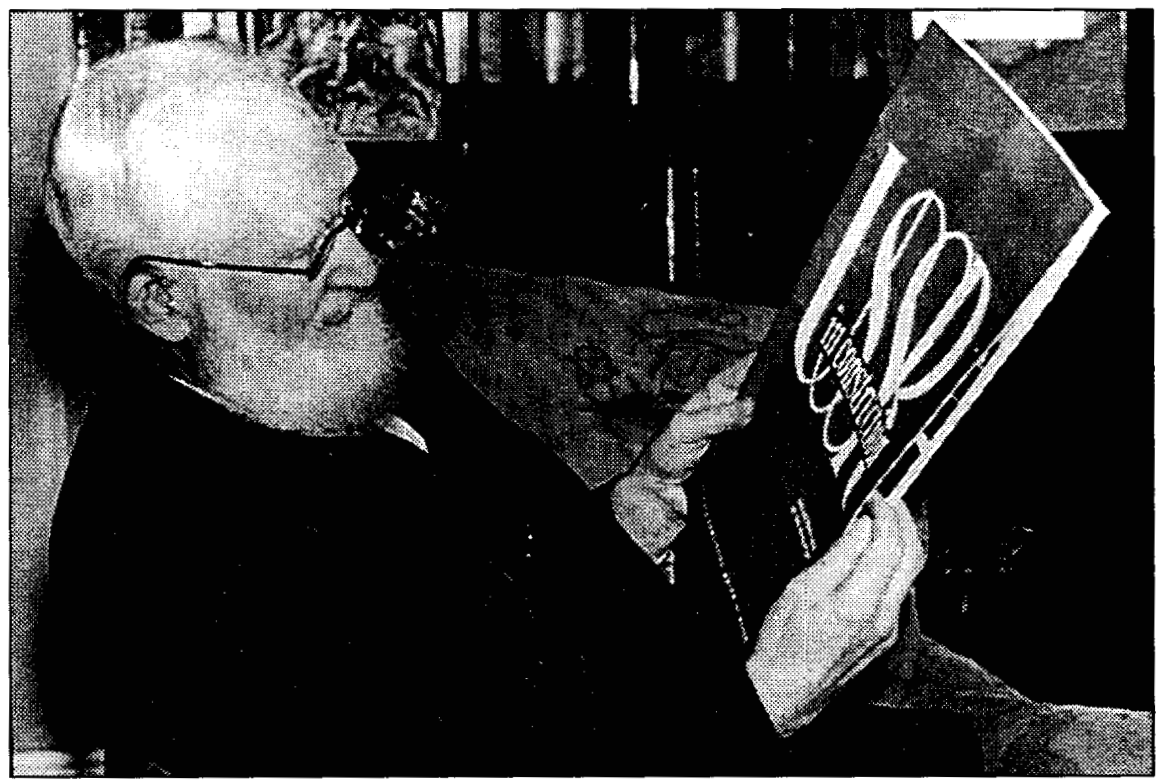

Figure 2: George Bernard Shaw examining USSR in Construction, November 1933. International Historical Press Photo Collection, Stockholm 
56 Left History 6.2

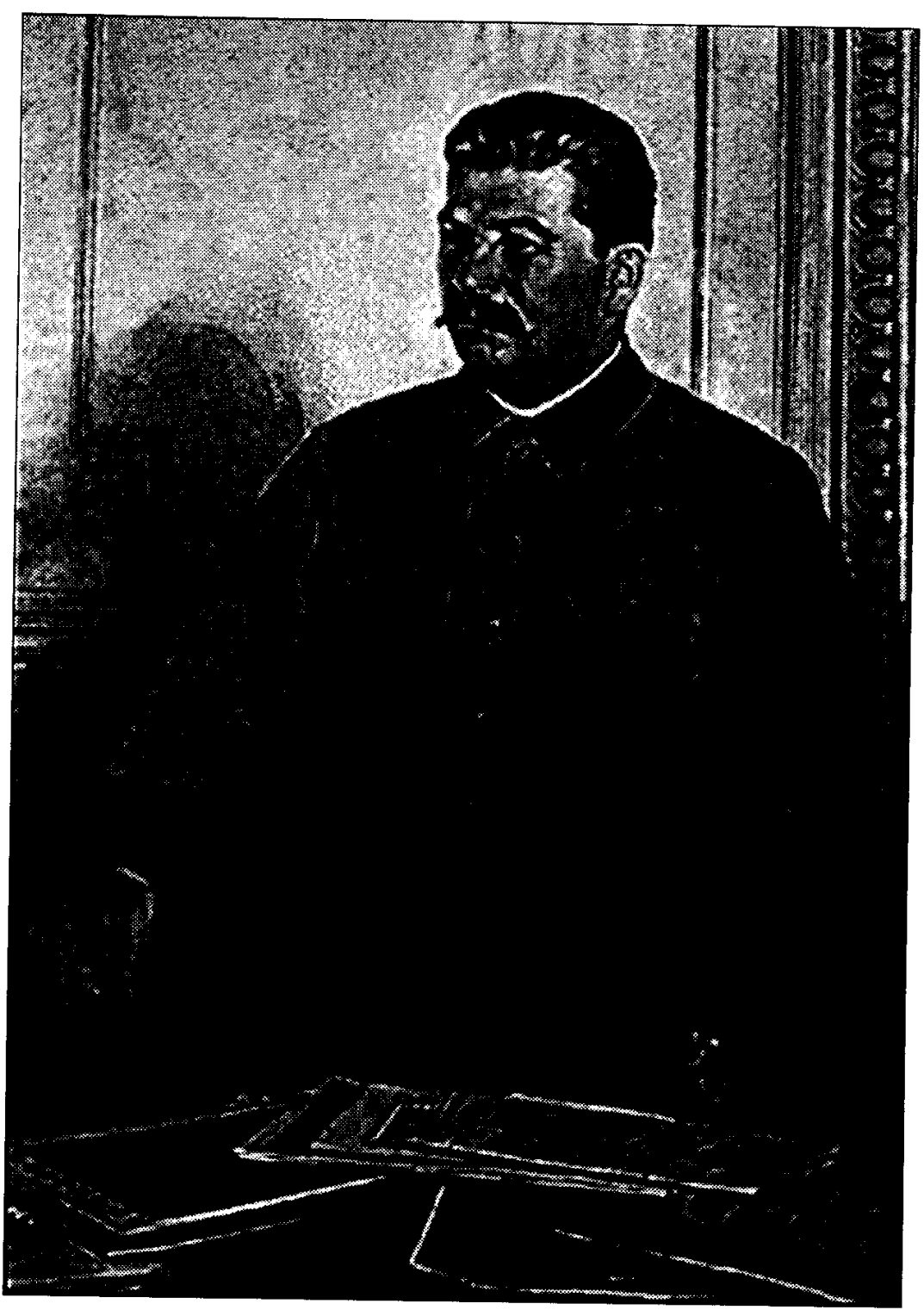

Figure 3: Isaak Brodskii, Stalin, 1937

State Russian Museum, Saint Petersburg 
documentary film would also be central to SSSR na stroike.

Another critical connection between the two magazines was their mutual aim of highlighting the economic and cultural achievements of the Soviet Union in a widely accessible, highly positive, affirmative manner - Nashi dostizheniia by means of words and SSSR na stroike by means of visual images. Setting aside self-criticism, Nashi dostizheniia chose to focus exclusively on the positive:

This magazine is needed to sharply differentiate our good from our bad. There is much that is good, but there is more of the bad. And, since the bad is more prevalent, the good is not visible enough.

That's why it's necessary to set apart the good, so that even those people who do not adequately understand the enormous significance of our labour and the greatness of our aims will see what we have already achieved and how we succeed in building the new life.

We will learn from the good. Only upon it may we build our new morality, those rules of conduct which will further elevate and define our labour energy and will compel us to fully sense the joy of creative life. ${ }^{7}$

Gor'kii's stance stemmed from his estimation of the caustic criticism prevalent in the Soviet press as a counter-productive waste of energy. ${ }^{8}$ Self-criticism led to intensely negative coverage of the Soviet Union in the foreign press, which made use of the highly critical coverage in such papers as Ekonomicheskaia zhizn '("Economic Life") to discredit the Soviet industrialization drive. Gor'kii conducted a campaign against self-criticism and even wrote Stalin about his concerns in this regard. ${ }^{9}$ The rejection of self-criticism anticipated Socialist Realism's emphasis on the positive representation of socialist reality, even at the risk of distorting or ignoring existing social conditions.

A proposal for a photographic supplement was discussed at a staff meeting of Nashi dostizheniia in February 1929. The concept for the new magazine may have initially been developed by the Ogonek joint-stock publishing company under the aegis of chairman and editor-in-chief Mikhail Kol'tsov, an innovative journalist and tireless promoter of Soviet photography. ${ }^{10}$ The pioneering Soviet illustrated magazine Ogonek began publication in April 1923 with the motto "No material without a photo or drawing." By 1929, Ogonek was appearing in an edition of almost 500,000, and its publishing house had established a small empire of popular Soviet magazines. Ogonek's founder was Kol'tsov, who began his journalism career making documentary films during the Russian Civil War and first encouraged Dziga Vertov to work in film. An innovative and visionary journalist, Kol'tsov played a central role in the development of Soviet photography and the popular illustrated press. Through Ogonek, Kol'tsov laid the groundwork of modern photojournalism in the Soviet Union. In addition to establishing national and international mechanisms for the production, distribution, and preservation of photographic 


\section{Left History 6.2}

material, Ogonek actively promoted the further development of Soviet photography through the establishment of the specialized photographic magazine Sovetskoe foto in 1926 . While SSSR na stroike may initially have been conceived of at Ogonek, Kol'tsov appears to have turned to Nashi dostizheniia due to a shortage of resources and doubts that his publishing house could produce such a magazine with sufficient technical quality. ${ }^{11}$ According to a report submitted to the Economic Council of the Russian Federation early in 1929, the overwhelming success of Ogonek's numerous popular publications had so over-burdened its printing shops that two-thirds of its publishing work was farmed out to other presses in 1928. This situation was further aggravated by a shortage of paper in $1929 .{ }^{12}$ By attaching the proposed magazine to Nashi dostizheniia, a publication produced by Gosizdat (the State Publishing House of the Soviet Union) under the editorial guidance of Gor'kii, Russian's most prestigious writer, these difficulties were more easily overcome.

However, Gor'kii was initially opposed to the creation of an illustrated supplement. On 3 March he wrote to Artemii Khalatov, head of Gosizdat and an editor of Nashi dostizheniia, in complaint:

I am the founder and editor-in-chief of the magazine Nashi dostizheniia. This means that I take primary responsibility for all that takes place under the aegis of the magazine. From the protocol of the 13th staff meeting, I learned of plans for the publication of an illustrated bi-weekly edition of Nashi dostizheniia under a different editorial board. I do not know why it was deemed necessary to publish such a magazine, nor do I know the composition of the editorial board. I highly fear that this magazine will not maintain the modest tone that we all considered necessary for Nashi dostizheniia. "Little pictures," in general, are not convincing. To be perfectly frank, this undertaking makes no sense to me and is not to my liking. ${ }^{13}$

Gor'kii's use of the diminutive "little pictures" (kartinki) indicates his contemptuous attitude towards photojournalism. While Kol'tsov modeled himself as a young protégé of the eminent author, the two editors initially had diametrically opposite views about the role of photography in journalism. However, Gor'kii's reaction was premature. A day or two after writing the above note, he received the protocol for a meeting of the editorial board of Nashi dostizheniia that contained further details about the proposed publication of an illustrated bi-weekly supplement. By 5 March Gor'kii had changed his mind about the photographic supplement, although he still had reservations about the overly hasty planning of the new publication.

Gor'kii visited the Soviet Union from May to October 1929, during which time plans for the new publication continued to develop and work began on a mock-up for the first issue. On 16 June 1929, Izvestiia published Gor'kii's speech at a special meeting of Nashi dostizheniia. After reviewing the aims, 
audience, and initial work of the Nashi dostizheniia, Gor'kii discussed future plans and announced the publication of an illustrated supplement:

In agreement with comrade Piatakov, it has been decided to enclose with each issue of [Nashi dostizheniia] the illustrated magazine $\mathrm{Na}$ stroike, which will be printed on good paper and will represent construction in the form of photographs and drawings. This is intended chiefly for abroad; there it is needed to know no less than here, because there are readers who sympathize with us there. ${ }^{14}$

In this same speech, Gor'kii stressed the mass nature of the audience of Nashi dostizheniia and its pedagogical aims, the education of the working masses of the Soviet Union. This audience was quite different from the proposed supplement's intended audience, foreign readers sympathetic to the Soviet Union. Initially conceived of as a supplement to Nashi dostizheniia, a magazine with the aim of educating Soviet peasants and workers, SSSR na stroike was initially intended for distribution abroad. The incompatibility of these two audiences and aims probably became evident during the planning of the new magazine, as SSSR na stroike appeared at the end of the year as an independent publication. This announcement is also notable in its reference to Piatakov, who was Chairman of the State Bank of the USSR (Gosbank) at that time. While the type of sympathies of the foreign audience is not specified, Piatakov's involvement in the matter indicates that financial considerations were the initial motivation for the foreign distribution of SSSR na stroike.

Prior to his return to Italy, Gor'kii examined the mock-up for the first issue. In his critical notes Gor'kii recollected that during planning it was resolved to present photographic material "so that there arises before the reader a more or less entire picture of construction" on individual themes related to socialist construction. Gor'kii faulted the mock-up for failing to do this: "In it the government's work is given an unorganized, fragmented appearance which cannot be adequately convincing to the observer-reader." $\mathrm{He}$ also questioned the representation of industrial processes and Soviet workers:

The mock-up of the first issue included photographs of several processes of labour: the assembly of engine cylinders, the testing of a machine tool, the assembly of turbines, et cetera. I do not think that we have introduced anything new into the work processes that will amaze foreigners. It is more likely that precisely these processes will display "the old way" the persistent negligent attitudes of workers towards materials and insufficiently intelligent attitudes about work. It is entirely possible that foreigners will look at the photographs and see workers, who stand around, smoke, and do not take part in work - intolerable behavior from the point of view of the "masters" of Europe and America. It makes no sense whatsoever to present photographs of workers who serve as spectators of the work of their comrades. ${ }^{15}$ 
Gor'kii's comments point to one of the central representational problems confronting the magazine: how to represent Soviet industrialization to Western European and American audiences in a manner that both minimized the backwardness of Soviet technology and highlighted the ideological difference of the Soviet system from capitalism. Gor'kii's reference to the "'masters' of Europe and America" suggests that the targeted audience included Western industrialists and capitalists.

The first issue of SSSR na stroike was published in December 1929. Gosizdat organized the efficient production of SSSR na stroike in various languages by using the same plates to print the photographic material for all versions; this visual ground was then over-printed with text in varying languages to produce the four different editions. On the whole, there was no significant difference in the content of the Russian and foreign language editions, excepting the absence of the slogan "Workers of the World Unite!" from the title pages of the foreign editions. ${ }^{16}$ However, the very first issue featured different editorial introductions in the Russian and foreign language editions. The English, French, and German language editions of the first issue were prefaced by brief introductions which are roughly comparable (see the introduction to the English edition, above). The aim set forth in the editorial statement is decidedly neutral: the documentary representation of the "colossal construction now taking place in the Soviet Union" by means of photography. While socialist construction could connote radical political and social transformation, the content of the first issue allows a more limited interpretation of it as industrialization. In contrast, the Russian editorial statement, allegedly written by Gor'kii, is politicized and outlines in detail the goals and methods of the new magazine against the context of the economic reconstruction of the Soviet Union. ${ }^{17}$ The Russian editorial is prefaced by a quotation from Stalin: "We advance at full steam along the path of industrialization towards socialism, leaving behind our age-old Russkie backwardness." 18 This citation initiates a central theme of the introduction: the magazine's representation of the transformation of the backward Russian empire into an industrialized Union of Soviet Socialist Republics. The statement describes the destruction of the economy during the "imperialist slaughter" of the First World and Russian Civil Wars, and the restoration of the economy under the leadership of the Communist Party. Claiming that the Soviet Union now stands "on the eve of a technical and cultural revolution," the lack of knowledge about these events is lamented:

But this grand labour is unknown in all its scope to our masses of workers and peasants. It is also unknown to the proletariat of Europe and that part of the technical and radical intelligentsia which secretly and overtly is sympathetic to us, the builders of a new form of state life. ${ }^{19}$

While the particular problem that the magazine confronted was almost 
identical to that of Nashi dostizheniia, the scope of its ambitions was far broader. Three distinct audiences are mentioned in this passage: Soviet workers and peasants, the European proletariat, and non-Soviet intelligentsia. Noting that statistics, diagrams, and verbal descriptions are often not sufficiently convincing and are subject to distortion in the hostile foreign press, photography is presented as a more objective method of representation, which overcomes these shortcomings:

In order to rob our enemies inside and outside the Soviet Union of the ability to distort and discredit the display of words and numbers, we decided to turn to drawing with light [svetopis], ${ }^{20}$ to the work of the sun - to photography. You do not accuse the sun of distortions, the sun illuminates what exists as it exists.

We should bring photography and cinema to the service of our construction. Photography and cinema are fully able to graphically and concisely present the enormous scale of construction work being carried out by the proletariat in the land of the Soviets. Such films as Turksib, The Murmansk Road and others, in spite of their number of shortcomings, brilliantly solve the task. It is necessary that cinema be closely occupied with the artistic representation of our construction. But photography should also be devoted to the service of construction not randomly, without system, but systematically and constantly. Photographic representations of our construction - dynamic representation at that should be accessible to all interested in our construction. The magazine USSR in Construction puts before itself precisely the task of the systematic representation of the dynamics of our construction by means of drawing with light.

The statement argues for the systematic application of photography in the representation of industrial construction and invokes the precedent of films that documented major construction projects of the late twenties. The editorial advocated the emulation of films like Turksib (1929), Viktor Turin's documentary about the Turkistan-Siberia Railroad that was widely screened and publicized both in the Soviet Union and abroad. ${ }^{21}$ Like Turksib, the magazine would attempt to document the progress of socialist construction in a dynamic manner. The statement concludes modestly noting the deficiencies of the first issue, especially its lack of dynamism. These shortcomings are credited to the lack of a systematic approach to the task of photographic representation, a problem that the magazine seeks to resolve.

Gor'kii's negative estimation of the first issue continued in his correspondence with the editorial board. The writer attacked the fragmented, incoherently organized photographic material and singled out several photographs as irrelevant. He also faulted the accompanying captions:

The texts need to be composed with complete accuracy. I find such 
modifiers as "almost," "approximately" and "equal to or about" impermissible because they give the impression of ignorance about what is being discussed. One should not speak about the hypothetical but only about what has been accomplished. ${ }^{22}$

Gor'kii wrote to Khalatov: "I can't say anything positive about the magazine $\mathrm{Na}$ stroike. Having worked on it for several months, having spent heaps of money, the people created something very insipid and almost deformed." ${ }^{23}$ In January 1930, a distressed Khalatov responded to this criticism. Admitting that there were many mistakes in the first issue, Khalatov viewed the very existence of the new magazine as an achievement and looked positively towards the future: "Now the matter is not how to lay out the magazine, but that such a magazine has now appeared." 24

\section{READERSHIP}

Once SSSR na stroike began publication, the editors then set about developing its readership and monitoring responses to it. While documentation regarding domestic readership remains scanty, archival records concerning the distribution of the magazine abroad provide insight into the development of a foreign readership. The audience initially targeted in the foreign distribution of SSSR na stroike may be divided into a number of distinct groups: foreign business and trade communities, representatives of foreign governments, intellectuals sympathetic to the Soviet Union, and foreign workers. Clearly, these diverse audiences had radically varying interests and expectations in relation to the Soviet Union. Given its emphasis on a maximum of visual material and a minimum of text, SSSR na stroike could provide different messages to different readers. For example, an issue on electrification might be read by an American businessman as an opportunity for the sale of technical equipment and expertise, by an intellectual as evidence of the transformation of the backwards Russia into a progressive modern society, or by a communist worker as proof of the ongoing realization of Lenin's revolutionary plans in the Soviet Union.

The publication of the magazine in a number of distinct editions reveals that the publishers conceived of their readership as a differentiated audience. ${ }^{25}$ In the first two years of publication, the foreign language editions were published in luxury and economy versions, which were intended for different audiences. ${ }^{26}$ The deluxe edition was distributed primarily to select foreign business concerns, publications, and Soviet representations, while the economy edition was published for foreign workers and intellectuals. The mastheads of both versions list the annual subscription price as five dollars (10 rubles), yet the luxury edition actually cost three times that amount to produce. ${ }^{27}$

Gosbank, The State Bank of the USSR, played a critical role in the initial 
introduction and distribution of the new magazine abroad. G.L. Piatakov, editor-in-chief of the publication, was also the chairman of Gosbank and a special "Board on the Question of SSSR na stroike" was established within the bank. For the first several issues, Gosbank purchased the entire initial print run of the foreign luxury editions. In 1930 Gosbank and the People's Commissariat of Trade (Narodnyi komissariat torgovli, hereafter Narkomtorg) purchased 3,500 subscriptions to the deluxe edition for distribution to their delegations abroad and to foreign firms. ${ }^{28}$ Responsible for all financial transactions related to Soviet foreign trade, Gosbank played a crucial function in all foreign business deals. Gosbank and Narkomtorg's role in the initial distribution of the foreign language editions indicates that the magazine's origins were closely connected to the financial and trade interests of the Soviet Union. With the start of the industrialization drive of the first five-year plan, the Soviet Union began to import foreign equipment and technical expertise on an unprecedented scale. Technical assistance was sought from the United States, France, Germany, and Great Britain and numerous foreign specialists and skilled technical workers were hired to work in the Soviet Union. This investment in foreign technology and personnel required massive payments in hard currency, which created a potentially crippling trade deficit for the Soviet Union. In order to pay for industrialization, the Soviet Union sought to increase its export of both finished products and natural resources, including agricultural products, anthracite coal, asbestos, furs, lumber products, manganese ore, oil, and phosphate fertilizer - the very natural resources and products which were regularly featured in SSSR na stroike. ${ }^{29}$

While the Soviet Union enjoyed a relatively fair balance of trade with most of its trading partners, the United States was an exception. An extensive analysis of Soviet-American trade published by Amtorg in 1930 asserted that Soviet purchases from the United States made up five-sixths of the total trade between the countries during the fiscal year ending September $30,1930 .{ }^{30}$ Soviet attempts to achieve a more favorable balance of trade were thwarted by the United States' refusal to recognize the Soviet Union. Severe restrictions on the extension of credit to the USSR were placed on both American banks and the sellers of commodities for shipment to the Soviet Union. Furthermore, both the importation of Soviet gold and the deposit of Soviet gold in the United States were prohibited. This made it more difficult for the Soviet Union to purchase goods and services from the United States. During 1930 accusations of dumping, of the use of forced labour in the Soviet lumber industry, and that Amtorg was a front for the Comintern, further hindered trade with the United States. ${ }^{31}$

Gosbank actively promoted and monitored the reception of this magazine abroad by collecting the comments of foreign readers. ${ }^{32}$ In May 1930 an extensive list of comments on the new magazine by a variety of foreign individuals and institutions was forwarded to F. N. Petrov, chairman of the All- 
Union Society for Cultural Relations Abroad (Vsesoiuznoe obshchestvo kul'turnoi sviazi s zagranitsei, hereafter VOKS). ${ }^{33}$ These responses provide insight on the nature of the foreign audience which SSSR na stroike initially sought to cultivate. The list is broken down into the following categories: 1 . Banks; 2. Industrial joint stock organizations and companies; 3. Members of British parliament; 4. Magazines and newspapers; 5. Politicians, literary figures, and public figures; 6 . Workers and Soviet delegations abroad. The list's composition provides further proof that the cultivation of Soviet trade and financial interests was a top priority for the magazine's editors; roughly twothirds of the 110 responses were from European and American banks and businesses, while responses from foreign workers and Soviet delegations abroad appear only as an addendum at the end of the document.

Several of the American and German banks which provided feedback on the new magazine had been involved in financial deals with the Soviet Union during the 1920s. For example, Chase National Bank and the Equitable Trust Company were leaders in circumventing restrictive American finance laws and providing credit to the Soviet Union. In 1928 Chase, the Amalgamated Bank of Chicago, and the Bank of Italy in San Francisco were partners in a failed attempt to float a Soviet bond issue in the United States. ${ }^{34}$ The reviews include evaluations from all of these financial institutions. Many respondents were members of the American-Russian Chamber of Commerce, an organization that was initially established in 1916 but became defunct after the Revolution and was reestablished in 1926 by a group of American businessmen interested in developing trade with the Soviet Union. ${ }^{35}$ Reviews of the magazine were submitted by the following Chamber of Commerce members: Chase National Bank, General Electric, Bertron Griscom \& Co., Westinghouse Electric International Company, International General Electric, Underwood Typewriter Company, and the Equitable Trust Company. All of these companies were involved in financing, provisioning, and advising the Soviet Union in the industrialization drive of the first five-year plan and most were represented in a Chamber of Commerce delegation of American businessmen that traveled in the Soviet Union during the summer of $1929 .{ }^{36}$ While most of the business reviews are anonymous, a number of prominent business leaders are featured in the document, including J.P. Morgan and Edsel Ford, chairman of the Ford Motor Company, with whom the Soviet Union had signed a $\$ 30$ million contract for the purchase of automobiles and technical assistance for the construction of an automobile factory in Nizhni-Novgorod in May 1929. ${ }^{37}$ The list also includes a review from Percival Farquhar, a financier and member of the American-Russian Chamber of Commerce, who provided consultation on the development of the Russian metallurgical industry for both the Tsarist and Soviet governments. ${ }^{38}$

The content of the majority of the reviews is not especially noteworthy. Most are brief and filled with the pleasantries expected of hopeful business 
partners. Edsel Ford's is typical: "I was very interested by the photographs and information contained in your magazine. I will be glad if you will continue to send me the magazine, which provides us the possibility to be up to date on the progress of your construction program." ${ }^{39}$ Ford's request for a subscription is also characteristic; many writers expressed interest in receiving future copies, while others indicated their intentions to subscribe to the magazine. The repetitive, formulaic quality of the reviews indicates that they were solicited by means of form letters, which accompanied complimentary issues of the magazine. Three reviewers stated that they would display copies of the magazine in their waiting rooms. One response suggests that this was done in response to a request: "I will be glad to exhibit one copy of this magazine in the waiting room, so that other people may have the possibility to form an impression of Russia for themselves." 40 In May 1930 Gor'kii reported to Khalatov that an acquaintance had seen three issues of the magazine in the waiting room of a Parisian bank. ${ }^{41}$

Concrete criticism and commentary also appeared in the reviews. Walter Loeb, a British respondent, was generally complementary but reserved criticism for the translation and suggested that individuals with greater mastery of English edit the text. ${ }^{42}$ Translations were awkward in the early issues and were a source of concern for the magazine, which actively sought to improve the quality of translation. The Director of the Reichsbank Fuchs in Berlin suggested that diagrams be included, "since they testify to progress in the most visual way."43 Reflecting upon his own experience visiting the Soviet Union, the reviewer for the International General Electric Company of New York suggested that the magazine expand their coverage beyond the documentation of industrial development:

I would like to suggest that in addition to industrial development, you should also show your accomplishments in the area of sanitation and public health. I personally saw many good things in this direction, and I am certain that people who have not visited the USSR know very little about this. ${ }^{44}$

Beginning with issue number 7-8 for 1930 such subjects were regularly included in SSSR na stroike - and it was precisely these themes that were best suited to distinguish Soviet conditions from capitalist conditions during the throes of the Depression.

The reviews reveal that another significant foreign audience targeted by the new magazine was foreign politicians. A member of the Soviet delegation to Great Britain, the Press Attaché I. Ioel'son, enthusiastically reported:

The magazine SSSR na stroike has created a big furor here. For example, when they showed Thomas a copy of this magazine, he was so delighted that he asked for it to be distributed to all the members of the Cabinet. The 
magazine has also been passed around among members of Parliament. "Among us," say the English, "it provokes astonishment and interest that in the USSR under Soviet power a factory or building has been constructed, where earlier there was just an empty space., 45

Responses from foreign politicians were predominantly limited to members of British Parliament. In 1921 England was the first major power to conclude a trade agreement with the Soviet Union and became the first to establish full diplomatic relations in $1924 .^{46}$ In May 1927 Great Britain broke off diplomatic relations with the Soviet Union; this act led to a sharp decline in Soviet purchases. Towards the end of 1929 diplomatic relations were re-established under a new Labour government and trade between the two countries was correspondingly stimulated. Among the reviewers of SSSR na stroike were the secretary of David Lloyd George and E.F. Wise, both of whom advocated the resumption of diplomatic relations during parliamentary debates in 1929.47 Lloyd George served as the prime minister of Great Britain from 1916 to 1922 , during which time Great Britain established a trade agreement with the Soviet Union, and was the leader of the British Liberal Party in 1930. Prior to his election to parliament in 1929, E.F. Wise had served as an economic advisor on foreign trade to CENTROSOYUZ, the Russian co-operative organization, from 1923 to 1929.48 As a Labour member of parliament, E.F. Wise contributed to the development of Soviet-British trade through such activities as speaking at a luncheon organized in 1929 by the British-Russian Gazette and Trade Outlook which was attended by representatives of British firms interested in doing business with the Soviet Union. ${ }^{49}$ Wise provided the following comment about the new magazine: "I congratulate you on the first issue of SSSR na stroike. One of its merits is its absolutely objective character. It goes without saying that I will do everything so that it will be seen by the greatest number of people." 50 Aside from further demonstrating his commitment to the promotion of trade with the Soviet Union in Great Britain, Wise's comment suggests the importance of the magazine's creation of a sense of objectivity. Soviet propaganda, especially that of the Communist International, was considered a violation of the sovereignty of British domestic affairs, and propaganda was one of the issues which led to the rupture in relations in 1927. By means of the purported objectivity of photography, the editors of SSSR na stroike could claim that the magazine documented "the truth." The practical need of the Soviet Union to develop better trade relations with the United States and Great Britain may have encouraged the adoption of a more "neutral" tone for this publication.

The investment of resources in the production of an expensive deluxe edition and the solicitation of reviews of SSSR na stroike from the international business community indicate that this foreign audience was of primary concern to the new magazine's editors. However, the publication of a less 
expensive edition indicated a desire to reach diverse foreign audiences. Khalatov, assistant editor of $\mathrm{Na}$ stroike, solicited the assistance of VOKS in distributing the economy edition:

In order to satisfy the demand for this magazine by individual subscribers and, in particular, foreign workers, Gosizdat is publishing an inexpensive edition of SSSR na stroike in those languages for the price of 10 rubles ( 5 dollars) for an annual subscription. However, the wide distribution of this magazine abroad will only be possible with the active participation of such social organizations as the Society for Cultural Ties with the USSR [VOKS], et cetera. I ask you to consider this matter and to render the appropriate assistance. ${ }^{51}$

While Khalatov endorsed the publication of less expensive edition for individuals and foreign workers, the lag in production of the economy version of the first issue (already three months delayed at the end of March 1930) indicates that publication of an affordable edition for foreign workers and sympathetic intellectuals was not a top priority..$^{52}$ Khalatov appealed to VOKS and other organizations to assist in the distribution of the magazine abroad. VOKS' mission was the cultivation of favourable relations with foreign cultured elites (artists, academics, educators, writers, cultural organizations, and sympathetic intellectuals). While regular subscribers from abroad could order the magazine through representatives of Mezhdunarodnaia kniga ("International Books," an international distributor for Soviet publications), VOKS also distributed issues of the magazine, purchasing copies in bulk from the Periodical Sector of Gosizdat. ${ }^{53}$ The geographic range of distribution by VOKS was extensive; aside from the industrialized English, French, and German speaking nations, copies of the magazine were literally sent around the world, to countries ranging from Portugal to Afghanistan. ${ }^{54}$ VOKS also included copies of the magazine in exhibitions that it circulated abroad, such as a Soviet photography exhibition that toured England during $1930 . .^{55}$ Due to financial constraints, VOKS was not able to send an unlimited number of magazines to its representatives abroad; hence, its distribution was selective. ${ }^{56}$ In 1930 and 1931, the American and British Sectors of VOKS distributed complimentary copies of USSR in Construction to and solicited responses from a variety of educators, social workers, members of British Parliament, and representatives of progressive cultural organizations. VOKS sent the following query out to recipients of USSR in Construction in September 1931:

For some time we have been sending you an illustrated journal. As we have received no confirmation from you, we should be interested to know if it has been reaching you safely. We should also be glad to hear your opinion on the journal and whether you would be interested to receive it in the future. ${ }^{57}$ 
This letter was sent to individuals throughout the British Commonwealth. Professor Archibald Vivian Hill of the Physiology Department of the University of London replied to VOKS:

Yes, I have been receiving the illustrated journal USSR in Construction, which you have been kind enough to send me. The photographs and their reproductions are excellent and I should be very glad to receive further copies as issued.

I have received also various papers containing political propaganda, speeches by George Bernard Shaw, etc. These do not interest me, so please do not trouble to send them in the future. ${ }^{58}$

Hill welcomed the receipt of the magazine, while distinguishing it from the Soviet political propaganda that he rejected. Hill perceived the photographs to be less ideologically tainted and more palatable to his taste than the overtly political texts that were also sent to him. In contrast, George Strauss, a Labour Party member of British Parliament, sent an entirely affirmative response:

I can assure you that I am extremely interested in this publication, which I consider is rendering an invaluable service to Russia and those abroad who are sympathetic to her ideals or admire her activities. I very much hope that you will continue to send me future copies. ${ }^{59}$

Strauss himself was sympathetic to Russia. A few months earlier in September 1931, he and two other Members of Parliament visited Russia and traveled to various industrial and agricultural sites. Upon their return to England, they published a highly positive pamphlet about their perceptions of the transformation underway in the Soviet Union. ${ }^{60}$ George A. Cornish, a professor of Geography at the Ontario College of Education of the University of Toronto, also replied affirmatively and informed VOKS that he had made both film and lantern slides from USSR in Construction. The film slides were intended "to be widely used in the schools of Canada," while the lanternslides were for his own lectures on Russia. ${ }^{61}$

American recipients of complimentary subscriptions from VOKS included several university professors who had recently visited the Soviet Union, such as Susan Kingsbury, a professor of social economy at Bryn Mawr College who authored a study on Soviet women factory workers, ${ }^{62}$ the philosopher John Dewey, ${ }^{63}$ and George S. Counts, an education theorist and the Associate Director of the International Institute of Teachers College, Columbia University. ${ }^{64}$ Some recipients had recently visited the Soviet Union, where they had been in contact with VOKS. In October 1931, Lena Madesin Phillips wrote and thanked VOKS for a complimentary subscription to USSR in Construction ${ }^{65}$ En route to a conference in Switzerland where she would establish the International Federation of Business and Professional Women in 
August 1930, Philips led a group of American women on a tour of Northern Europe that included an eight-day visit to Russia. While in Moscow, the delegation met with women members of the Communist party at a tea arranged by VOKS. ${ }^{66}$ Clarence Pickett, Executive Secretary of the American Friends Service Committee, wrote VOKS to acknowledge the receipt of USSR in Construction; Pickett had also briefly visited the USSR in $1930 .{ }^{67}$ The magazine was also distributed to foreign institutions, cultural organizations, and libraries. Among the responses collected by Gosbank were reviews from the library of the League of Nations (Geneva), the Biblioteque Nationale (Paris), Duke University, and the Austrian Trade Museum. Complimentary subscriptions also appear to have been provided to numerous American university libraries, such as the University of Michigan. VOKS also assisted in the distribution of the magazine to foreign cultural organizations. The head of the Anglo-American Sector of VOKS wrote the editorial offices of SSSR na stroike in July 1930 to request that a complete set of the journal be sent to $\mathrm{H}$. Chapman, secretary of the London-based International Federation of Housing and Town Planning, who had offered to print an announcement and review of the magazine in the Bulletin of the Federation. ${ }^{68}$

SSSR na stroike was also distributed to foreign workers and Soviet activists. The extensive list of reviews compiled by Gosbank includes the responses of several workers and labour activists from France, Germany, and Czechoslovakia. These comments are set off by the heading "Notes from letters received by the International Committee of Miners"; this suggests that copies of the magazine were distributed by Soviet agencies involved with the international worker's movement. The response of the editorial board of a Canadian worker's magazine was exceptionally vivid:

We have illustrated magazines here, but nothing like that. There is The Graphic - it is a large magazine. But it's not the same thing. I want to point out here the photographs. Wonderful, extraordinary, thrilling pictures of labour. Try to imagine for yourself such a photographer in our industry! Englishmen aren't able to do this ... Bent over this magazine, you daydream. Some day, yes, some day our workers will do as the Russians. Only then can we build in the same way. ${ }^{69}$

Clearly, this reader had a very different reaction to the magazine than Edsel Ford. Rather than responding to the USSR as a potential trading partner, the editor envisions a Soviet Canada through the images presented in the magazine. However, few workers had the opportunity to daydream over the images in SSSR na stroike. The French worker's magazine La Vie Ouvrière indicated reservations about its accessibility: "...we allow ourselves to express the wish that your magazine will be more accessible to the worker." 70 This statement is ambiguous; was the problem of access related to the magazine's content or, more simply, of physical availability and cost? Probably both. The 
extremely expensive magazine was not readily accessible to foreign workers, let alone to ordinary individuals and institutions. In August 1931 the secretary of the Plenipotentiary representative of the Soviet Union in Poland informed the press office Commissariat of Foreign Affairs that the contemporary economic crisis had made the subscription to the magazine by local institutions and individuals highly problematic. ${ }^{71}$ The high price did not necessarily exclude workers from its audience, but it did encourage communal forms of consumption, as suggested in the review by the worker from Czechoslovakia: "The magazine SSSR na stroike made me especially glad. It is passed from hand to hand. Our comrades and unorganized workers study it with eager interest." 72 The Comintern was also involved with the foreign distribution of the magazine, however its officials were rather ambivalent about the publication. In 1933 the Agitational Propaganda Sector's Commission on the Popularization of Socialist Construction was highly critical of the effectiveness of SSSR na stroike for propaganda purposes, due to its limited scope. Despite initial attempts to publish an economy edition, the Comintern Commission report on printed propaganda described the magazine as "accessible only to the wealthy customer." Given the limited budget for photographic propaganda, the Commission advocated the development of a cheaper publication modeled after the magazine and literally referred to a "people's edition" of SSSR na stroike. ${ }^{73}$

In December 1930 Lopez Cardozo, a member of the Dutch Communist Party, sent the editors of SSSR na stroike his reactions to the magazine. Claiming to have shown the magazine to roughly 3,000 workers of a metalworking factory in Utrecht, Cardozo concluded that for foreigners and barely conscious workers, it was necessary to depict not only machines, buildings, factories, and plants, but also to show Soviet workers themselves and all aspects of their lives. Cardozo asserted that this would reveal the characteristic difference between the lives of the workers of the capitalist and Soviet countries. Noting that the capitalist worker is a slave to the much-hated machine, he urged the editors to show happy Soviet workers using machines. Cardozo concluded his letter:

If you answer me, "Our magazine is intended primarily for the Russian worker," then my observations are superfluous. Should this be the case, then would it be possible to occasionally print an issue composed primarily for the foreign worker - the little conscious and still not conscious - about the progress towards the realization of the wonder of Communist life in the USSR? ${ }^{74}$

Cardozo would have been shocked to discover that the foreign edition of magazine was intended primarily for industrialists and only secondarily for workers. Nevertheless, the magazine did increasingly conform to Cardozo's suggestion to show worker's lives in such issues as "The Giant and The 
Builder" (1932, no. 1), which presented simultaneously the story of the construction of the Magnitogorsk steel plant and the transformation of the illiterate peasant Viktor Kalmykov into an educated worker and Party member.

While the cultivation of a foreign audience was clearly a priority of SSSR na stroike's editors at the time of its initial publication, the development of a domestic audience was of no less importance. From the very first year of publication, issues of SSSR na stroike were published in conjunction with Party Congresses and other events of special significance to an elite Soviet audience. This began with the publication of an issue (1930, no. 5-6) in conjunction with the 16th Party Congress and the inclusion of a greeting to the Congress on the cover of the Russian edition. ${ }^{75}$ The greeting to the delegates was not a mere whim; in May 1930 Khalatov wrote Gor'kii about plans to publish this issue of SSSR na stroike and an issue of Nashi dostizheniia in time for the Party Congress. "The Giant and The Builder" (1932, no. 1) was published to coincide with the initial firing of the first blast furnaces at Magnitogorsk and was distributed at the 17 th Party Conference, devoted to industrial development. ${ }^{76}$ "Four Bolshevik Victories" $(1934$, no. 2$)$ was published in conjunction with the 17th Party Congress. ${ }^{77}$

During the first years of publication, foreign specialists and technology were often featured in SSSR na stroike as an integral part of the construction of socialism. However, once heavy investment in foreign technology began to decline sharply and Soviet industry became increasingly self-reliant, the content of the magazine changed significantly. By 1934, foreign technology and specialists were almost absent from the pages of the magazine. When foreigners did appear, they were usually represented as visitors who marveled at Soviet achievements or testified to the progress of socialist construction. Analysis of the number of copies printed for the English and Russian versions suggests that the production of the magazine for foreign consumption was of decreasing significance by 1934. Print run figures appear in all Russian issues and were included in the foreign editions from December 1931 to November 1934 (see appendix A). These figures indicate that the production of the magazine for foreign distribution steadily declined. Political developments during 1933 surely had an impact on the distribution of the foreign editions. Hitler's rise to power and the aftermath of the Reichstag Fire doubtlessly had disastrous consequences on the distribution of UdSSR im Bau in Germany, while the United States' recognition of the Soviet Union in November 1933 probably diminished the importance of USSR in Construction. Another indicator of the decline of foreign circulation is the scarcity of later issues of USSR in Construction in American library collections. Despite this apparent decline in foreign circulation, the Russian print-run figures remained strong (Appendix B). Circulation figures reached a low point in 1936 (the year of Piatakov's arrest) but quickly returned to robust levels for the remainder of the decade. 


\section{Left History 6.2}

Who was reading SSSR na stroike in the Soviet Union? Advertisements in Russian were included in a number of domestic issues of SSSR na stroike during 1934. An advertisement for Newton Chambers and Company, an English firm, is tipped into the back of the first issue for 1934. The theme of this issue was the Bobriki Chemical Complex, a construction project for which Newton Chambers had provided equipment and technical expertise. This advertisement is aimed at the Soviet techno-industrial elite, the captains of industry responsible for building and equipping new industrial complexes. A few months later an advertisement for gramophone records and record players was published which featured RCA Victor products available for purchase at Torgsin, a hard currency store that sold imported goods. The records advertised included jazz, tango, classical music, and recordings by the musical movie stars Pola Negri and Lily Pons. It is doubtful that the ordinary Russian worker had access to such imported luxuries. SSSR na stroike was one of the most expensive Soviet periodicals published during this period ${ }^{78} \mathrm{~A}$ lavishly printed publication, SSSR na stroike may itself have served as a prized consumer item for the new Stalinist elite.

The most convincing proof of a conscious attempt to cater to an elite Soviet audience was the appearance of special luxury Russian versions of certain issues of the magazine. Printed only in Russian, some of these deluxe variants were far more elaborate than the expensive foreign editions published in 1930 and 1931. The first issue to appear in different Russian variants was "Four Bolshevik Victories" (1934, no. 2), published in conjunction with the 17 th Party Congress. Special copies of this issue were wrapped in fabric from the Stratostrat "SSSR," a Soviet high altitude exploration balloon, and contained a gramophone record of speeches by the four commanders of the Soviet expeditions that it highlighted. ${ }^{79}$ During 1935 numerous issues were published with distinct variants. The deluxe variant of the January issue, devoted to the Maksim Gor'kii Agitational Air Squadron, features a silvery aluminum cover with an image of an airplane but no other text (the cover usually included the name of the magazine). The final issue for 1935, "Fearless Soviet Parachutists," features elaborate paper folds in both the regular and deluxe versions. The deluxe version utilizes better materials, includes details such as a metallic aluminum cutout airplane, features even more paper folding and has a parachute which literally unfurls before the reader like a children's pop-up book. The design differences necessitated different layouts for various parts of the magazine, rendering the two versions as essentially distinct publications. In addition to these elaborate variants, a special album was produced which bound together all of the issues for 1935 in an elaborate navy blue leather binding with red embossed lettering. Nicknamed the "Voroshilov" edition, this volume was purportedly produced in a limited edition for distribution to members of the Politburo and Central Committee. ${ }^{80}$ Another notable luxury version that appeared in 1936 was devoted to Soviet Georgia. 
This deluxe variant is printed on higher quality paper and gold leaf detail appears on a number of exceptionally richly printed pages. This issue received laudatory reviews in both Pravda and Za industrializatsiia, the newspaper of the Commissariat of Heavy Industry. ${ }^{81}$

Around 1933 the editors' interest in reaching the foreign trade and political community was eclipsed by efforts to cater to the Soviet political and managerial elite. Correlation of this shift with the chronology of the work of prominent avant-garde artists on the magazine reveals that these individuals began to contribute to SSSR na stroike around the time that the Soviet elite emerged as the paramount ideal audience. Appendix $D$ lists the issues designed by two teams of artists, El Lissitzky/Sophia Lissitzky-Küppers and Aleksandr Rodchenko/Varvara Stepanova. Circulation figures for the English edition were already dropping when Lissitzky executed his first issue of SSSR na stroike (1932, no. 10). This suggests that the primary audience for this vanguard work was probably the Soviet leadership. In April 1933, Khalatov reported to Gor'kii the proceedings of an editorial board attended by Piatakov (a member of the Central Committee), Kalmanovich (a candidate member of the Central Committee), and other editors:

\footnotetext{
We painstakingly discussed the issues of the magazine devoted to Dneprostroi [1932, no. 10] and the Red Army [1933, no. 2], the design of which made extensive use of the photomontage method. According to the general opinion of the editorial board their design is, without argument, successful, but we declared it necessary not to over use photomontage, in order that the magazine not lose its simplicity and naturalness. ${ }^{82}$
}

The issues discussed were the first two designs that El Lissitzky executed for SSSR na stroike. While wary of the potential disruption of a sense of neutral objectivity by the overuse of avant-garde representational strategies, the editors found Lissitzky's photomontage designs to be highly successful. In essence, the application of vanguard design methods to the production of SSSR na stroike was endorsed by the editors, while caution was urged so that the sense of objectivity conveyed by photography would not be disrupted by abrupt montage juxtapositions. In the next few years, both teams of artists executed prominent luxury editions intended for the Soviet leadership. Lissitzky and Lissitzky-Küppers designed "Four Bolshevik Victories" $(1934$, no. 2) and "The 15th Anniversary of Soviet Georgia" (1936, no. 4-5), while Rodchenko and Stepanova authored the elaborate issue "Fearless Soviet Parachutists" (1935, no. 12). The work of these Soviet avant-garde artists on the magazine largely conformed to the dictates set forth by at the editorial board meeting in 1933; montage techniques were tempered to promote a sense of "simplicity and naturalness."

Constructivist photomontage was deployed to create a fantasy image of 


\section{Left History 6.2}

the new Soviet state for consumption by the new Stalinist elite. The photomontage essays published in SSSR na stroike affirmed the new elite's achievements in the construction of socialism in the Soviet Union. As Sheila Fitzpatrick has argued, a new Stalinist administrative and professional elite emerged in the Soviet Union in the 1930s. ${ }^{83}$ The problematic split of bourgeois professional experts and "Red" administrators that existed in the 1920s was overcome by the training and rapid promotion of new experts with the proper class background "from the factory bench." While SSSR na stroike had initially been conceived with a foreign elite in mind, the luxury publication was eagerly embraced by the new Stalinist elite. It simultaneously fulfilled a variety of needs on the part of this new elite. It provided them with a valuable cultural resource - a Communist alternative to Fortune Magazine. It also offered them an image of Soviet society and industrialization that bolstered their sense of mastery and leadership.

In conclusion, I return to the representations of magazine consumers introduced at the start (figs. 1-3). While George Bernard Shaw very likely did receive complimentary copies of USSR in Construction, ${ }^{84}$ it seems highly improbable that SSSR na stroike was regularly distributed at collective farms. Both photographs are from the collection of the International Historical Press Photo Collection in Stockholm and are part of a comprehensive archive of Soviet press photographs that were distributed internationally during the 1930 s. ${ }^{85}$ They are publicity photographs that sought to cultivate favorable attitudes towards the Soviet Union. Inexpensive photographs churned out in large numbers, they are fundamentally different from state portraits in oil on canvas. In Isaak Brodskii's portrait of Stalin, SSSR na stroike is displayed prominently on a desk before the leader/reader; other periodicals scattered on the desk include a copy of a foreign language edition of the magazine, as well as copies of Izvestiia, Pravda, Prozhektor (an illustrated supplement of Pravda), and Na stroike MTS i sovkhozov (a spin-off publication of SSSR na stroike). This portrait provides visual evidence that by 1937 SSSR na stroike had become required reading for the Soviet elite and that Stalin was its ultimate ideal subscriber. 
When Photographs Speak, To Whom Do They Talk?

Appendix A: Print run statistics for Russian and Foreign Editions

\begin{tabular}{|c|c|c|c|c|c|}
\hline \multicolumn{2}{|c|}{ Year Issue } & \multirow{2}{*}{$\begin{array}{l}\text { Russian } \\
66,600\end{array}$} & \multirow{2}{*}{$\begin{array}{l}\text { English } \\
12,055\end{array}$} & \multirow{2}{*}{$\begin{array}{l}\text { French } \\
3,125\end{array}$} & \multirow{2}{*}{$\begin{array}{r}\text { German } \\
5,450\end{array}$} \\
\hline 1931 & 12 & & & & \\
\hline \multirow[t]{12}{*}{1932} & 1 & 59,000 & 10,140 & 2,300 & 5,185 \\
\hline & 2 & 58,700 & 9,650 & 4,400 & 6,850 \\
\hline & 3 & 88,700 & 10,100 & 4,350 & 6,850 \\
\hline & 4 & 86,850 & 10,885 & 4,630 & 7,635 \\
\hline & 5 & 87,350 & 10,650 & 4,450 & 7,550 \\
\hline & 6 & 89,250 & 9,850 & 3,750 & 7,150 \\
\hline & 7 & 88,450 & 9,350 & 4,150 & 8,050 \\
\hline & 8 & 88,450 & 9,350 & 4,150 & 8,050 \\
\hline & 9 & 88,450 & 9,350 & 4,150 & 8,050 \\
\hline & 10 & 88,750 & 9,350 & 4,150 & 7,750 \\
\hline & 11 & 75,850 & 9,150 & 4,350 & 7,650 \\
\hline & 12 & 78,050 & 8,300 & 3,800 & 6,850 \\
\hline \multirow[t]{12}{*}{1933} & 1 & 60,250 & 9,500 & 4,650 & 11,000 \\
\hline & 2 & 60,250 & 9,500 & 4,650 & 11,000 \\
\hline & 3 & 65,665 & 10,005 & 4,370 & 8,945 \\
\hline & 4 & 59,400 & 7,300 & not available & 6,950 \\
\hline & 5 & 59,400 & 7,400 & 3,850 & 6,850 \\
\hline & 6 & 59,400 & 7,400 & 3,850 & 6,850 \\
\hline & 7 & 59,400 & 7,400 & 3,850 & 6,850 \\
\hline & 8 & 52,840 & 6,490 & 3,600 & 6,825 \\
\hline & 9 & 46,250 & 6,229 & 3,825 & 5,720 \\
\hline & 10 & 46,250 & 5,998 & 3,825 & 5,720 \\
\hline & 11 & 37,495 & 5,255 & 3,260 & 4,788 \\
\hline & 12 & 45,505 & 5,385 & 3,474 & 5,098 \\
\hline \multirow[t]{10}{*}{1934} & 1 & 42,145 & 5,725 & 3,559 & 4,373 \\
\hline & 2 & 43,449 & 6,835 & 3,764 & 5,173 \\
\hline & 3 & 100,595 & 5,900 & 3,690 & 4,530 \\
\hline & 4 & 101,040 & 6,145 & 3,735 & 4,425 \\
\hline & 5 & 101,040 & 5,945 & 3,985 & 4,375 \\
\hline & 6 & 55,295 & 6,045 & 4,035 & 4,625 \\
\hline & $7-8$ & 53,586 & 6,600 & 4,897 & 4,917 \\
\hline & 9 & 55,010 & 6,235 & 4,345 & 4,410 \\
\hline & 10 & 56,640 & 4,940 & 4,875 & 4,795 \\
\hline & 11 & 56,030 & 6,240 & 4,330 & 4,445 \\
\hline
\end{tabular}

Source: Print-run figures published in individual issues of the various language editions of SSSR na stroike. 


\section{Left History 6.2}

\section{Appendix B:}

Average print-run per issue per year for Russian edition, 1930-1941

\begin{tabular}{|c|c|c|}
\hline 1930 & 60,367 & \\
\hline 1931 & 78,370 & \\
\hline 1932 & 81,487 & \\
\hline 1933 & 54,342 & \\
\hline 1934 & 65,533 & \\
\hline 1935 & 57,330 & \\
\hline 1936 & 37,613 & (year of Piatakov's arrest) \\
\hline 1937 & 60,368 & \\
\hline 1938 & 65,880 & \\
\hline 1939 & 76,730 & \\
\hline 1940 & 71,016 & \\
\hline 1941 & 74,350 & \\
\hline
\end{tabular}

Source: Print-run figures published in individual issues of SSSR na stroike.

Appendix C: Annual Russian and English edition subscription prices, 1930-1941

$\begin{array}{ccc}\text { Year } & \text { Russian price } & \text { American price } \\ 1930 & 10 \text { rubles } & 5 \text { dollars } \\ 1931 & 12 \text { rubles } & 5 \text { dollars } \\ 1932 & 15 \text { rubles } & 5 \text { dollars } \\ 1933 & 21 \text { rubles } & 5 \text { dollars } \\ 1934 & 21 \text { rubles } & 4 \text { dollars } \\ 1935 & 21 \text { rubles } & 4 \text { dollars } \\ 1936 & 30 \text { rubles } & 4 \text { dollars } \\ 1937 & 42 \text { rubles } & 4 \text { dollars } \\ 1938 & 42 \text { rubles } & 4 \text { dollars } \\ 1939 & 42 \text { rubles } & 3 \text { dollars } \\ 1940 & 42 \text { rubles } & 3 \text { dollars } \\ 1941 & 42 \text { rubles } & 3 \text { dollars }\end{array}$

Source: Subscription information printed in individual issues of SSSR na stroike and USSR in Construction. 
Appendix D: Issues designed by Lissitzky, Rodchenko, and Stepanova

Issues of SSSR na stroike designed by El Lissitzky \& Sofia Küppers-Lissitzky Issues marked with an asterisk were credited to El Lissitzky alone.

\begin{tabular}{|c|c|c|}
\hline Year & Issue & Subject \\
\hline 1932 & $10 *$ & Dneprostroi \\
\hline \multirow[t]{2}{*}{1933} & $2 *$ & 15th Anniversary of the Red Army \\
\hline & $9 *$ & The Soviet Arctic \\
\hline \multirow[t]{3}{*}{1934} & 2 & Four Bolshevik Victories \\
\hline & 6 & Soviet Science \\
\hline & 10 & The Epic of the Cheliuskin \\
\hline 1935 & $5 *$ & $15^{\text {th }}$ Anniversary of the Azerbaijan Oil Industry \\
\hline \multirow[t]{2}{*}{1936} & $4-5 *$ & $15^{\text {th }}$ Anniversary of Soviet Georgia \\
\hline & 10 & Kabardino-Balkarian Autonomous Region \\
\hline \multirow[t]{3}{*}{1937} & 1 & The Workers and Peasants Red Army \\
\hline & 3 & Peoples of the Ordzhonikidze Territory (Northern Caucasus) \\
\hline & $9-12$ & The Stalin Constitution \\
\hline 1938 & $5-6$ & The Far Eastern Territory \\
\hline 1939 & 6 & The Korobov Family \\
\hline \multirow[t]{4}{*}{1940} & 1 & The Stalin Grand Canal of Ferghana \\
\hline & $2-3$ & Western Ukraine and Western Byelorussia \\
\hline & 10 & Bessarabia and Northern Bukovina \\
\hline & 11 & Building the Red Navy \\
\hline 1941 & 3 & Innovators of Socialist Labor \\
\hline
\end{tabular}

Issues of SSSR na stroike designed by Aleksandr Rodchenko \& Varvara Stepanova Except for the first issue (1933, No. 12), all issues were co-designed by the artists.

\begin{tabular}{|c|c|c|}
\hline Year & Issue & Subject \\
\hline 1933 & 12 & The Baltic-White Sea Canal \\
\hline \multirow[t]{2}{*}{1935} & 11 & $15^{\text {th }}$ Anniversary of Kazakhstan \\
\hline & 12 & Fearless Soviet Parachutists \\
\hline 1936 & 8 & Soviet Timber Exports \\
\hline 1937 & 5 & Soviet Gold \\
\hline \multirow[t]{3}{*}{1938} & 2 & Moscow-Volga Canal \\
\hline & 4 & Election of the Supreme Soviet of the USSR \\
\hline & $11-12$ & Kiev: Capital of the Ukrainian SSR \\
\hline \multirow[t]{2}{*}{1939} & 9 & Soviet Agricultural Exhibition (VSKhV) \\
\hline & $11-12$ & Stalin Collective Farm \\
\hline 1940 & 7 & Vladimir Mayakovsky \\
\hline 1941 & 2 & GOELRO \\
\hline
\end{tabular}




\section{Left History 6.2}

1 Research for this article was made possible by the support of the following institutions: The Center for Advanced Study of the Visual Arts of the National Gallery of Art, Washington, D.C.; The International Research Exchange Board; The Kennan Institute for Advanced Russian Studies; and The Center for Russian and Eastern European Studies of the University of Michigan. Special thanks to Assya Humesky for proofreading my translations and to Larry Zeman and David King for making their collections available to me.

2 Victor Margolin, The Struggle for Utopia: Rodchenko, Lissitzky, Moholy-Nagy, 19171946 (Chicago 1997), 166-167. Margarita Tupitsyn, "From Factography to Mythography: The Final Phase of the Soviet Photographic Avant-Garde," Gabriele Gorzka (ed.), Kultur im Stalinismus: sowjetische Kultur und Kunst der 1930er bis 1950er Jahre (Bremen 1994), 207. Horacio Fernandez, Fotografia Pública: Photography in Print, 1919-1939 (Madrid 1999), 226-227. In a typical passage, Tupitsyn has asserted "The ambitious goal of the IZOGIZ magazine USSR in Construction was to provide propaganda that would reach well beyond the borders of the Soviet Union. Having successfully completed the first Five-Year Plan, Stalin wanted to provide the West with a positive view of Soviet Life and to counteract possible misrepresentations propagated by its enemies." Tupitsyn, The Soviet Photograph 19241937 (New Haven 1996), 127. Tupitsyn's chronology is inaccurate; SSSR na stroike began publication near the start of the First Five-Year Plan. This passage also exemplifies a problematic totalitarian model; all Soviet cultural developments are credited to a total dictator. By blaming Stalin for all the horrors of his time - from the purges to bad art - cultural producers of his time have been freed from any accountability and their creative contributions have been obscured.

3 Piatakov was editor-in-chief from 1930 until June 1936. Ezhova appeared on the editorial board for issues 1935, no. 6 to 1938, no. 7 and was assistant editor-in-chief from 1937, no. 1 to 1938 , no. 7, shortly before her arrest. While engaged in extensive research in various archives - including the State Archive of the Russian Federation (GARF), the Russian State Archive of Economics (RGAE), The Russian State Archive of Literature and Art (RGALI), The Russian Center for the Preservation and Storage of Documents of Recent History (RTsKhIDNI), and the Gor'kii Archive at the Institute of World Literature (IMLI) - I have located numerous documents related to SSSR na stroike, but I have not found the papers of the magazine itself.

${ }^{4}$ For the trial, see Robert Conquest, The Great Terror: A Reassessment (Oxford 1990), 147-167. For Piatakov's rehabilitation, see "O tak nazyvaemom 'Paralell'nom Antisovetskom Trotsistskom Tsentre," Izvestiia Ts.K. KPSS 9 (September 1989), 30-50. ${ }^{5}$ One significant shortcoming of recent scholarship on SSSR na stroike has been an emphasis on the visual analysis of a limited number of issues associated with renowned artists and photographers. In addition to ignoring the contributions of other individuals and exaggerating the authorial role of a limited number of prominent figures, such an approach often fails to consider broader issues such as the production, distribution, and reception of the magazine. In this article I have intentionally avoided visual analysis of images from the magazine as a strategy for calling attention to other concerns that need to be addressed in the study of Soviet visual culture.

${ }^{6}$ Maksim Gor'kii, "O 'malen'kikh' liudiakh i velikoi ikh rabote," Nashi dostizheniia 1929 , no. 1,5 .

${ }^{7}$ Gor'kii, “O 'malen'kikh' liudiakh i velikoi ikh rabote," 10. 
8 For Gor'kii's stance on self-criticism in relation to Nashi dostizheniia, see E.I. Cherniak, "M. Gor'kii i zhurnal Nashi dostizheniia," Trudy Moskovskogo gosudarstennogo istoriko-arkhivnogo instituta 18 (1963), 295-312.

9 Gor'kii to Stalin, 27 November 1929, “A.M. Gorky: Selected Correspondence," Political Archives of the Soviet Union 1.2 (1990), 177-180.

${ }^{10}$ Gor'kii, who was in Sorrento, Italy, at the time, reacted negatively upon learning of the proposed plans and demanded clarification from the editors about a resolution that mentioned the transfer of an illustrated bi-weekly magazine from Ogonek to Nashi dostizheniia. Gor'kii to the Secretariat of Nashi dostizheniia, end of February 1929, $M$. Gor'kii i sovetskaia pechat', book 2, Arkhiv A.M. Gor'kogo, vol. 10 (Moscow, 1964), 122. The initial conception of the magazine within Ogonek may account for the contributions of many of its staff members to SSSR na stroike as editors, office managers, translators, and photographers, often working simultaneously for both publishing organizations. Individuals affiliated with both Ogonek and SSSR na stroike include: editors Kol'tsov and Semen Uritskii; art director V.P. Mikulin; photographers Arkadii Shaikhet and Elizaveta Mikulina; translator and photographer Vladimir Chumak; translator Padraic Breslin; and artist Nikolai Troshin.

11 The majority of an Ogonek board meeting on 15 July 1929 was devoted to discussion of the substandard quality of printing and production of publications. Efim Zozulia reported: "Ogonek is filthily printed. The reproduction of photographs is disgraceful, the retouching is scandalous." Gosudarstvennyi arkhiv Rossisskii federatsii (GARF), fond A-299 (Aktsionernoe izdatel'skoe obshchestvo "Ogonek"), op. 1, d. 7, 1. 14.

12 GARF, fond A-2306 (Ministerstvo prosveshcheniia RSFSF), o. 69, d. 2088, 1. 14.

${ }^{13}$ Gor'kii to A.B. Khalatov, 3 March 1929, M. Gor'kii i sovetskaia pechat', book 1, 154. 14 "Reorganizatsiia zhurnala Nashi dostizheniia: M. Gor'kii o zadachakh zhurnala," Izvestiia, 16 June 1929.

15 "Zamechaniia k planu l-go No. Stroiki, 1929," M. Gor'kii i sovetskaia pechat', book $1,294$.

16 The absence of the slogan suggests an intended foreign audience that might be antagonized by a call for world proletarian revolution. However, it may also reflect the editors' desire to avoid censorship in the distribution of the magazine abroad. Without the slogan, the magazine was less likely to be banned by foreign governments as noxious Communist propaganda.

17 For a draft of the statement published in 1951, see M. Gor'kii, Povesti, vospominaniia, publitsistika, stat'i o literature, Arkhiv A.M. Gor'kogo, tome 3 (Moscow 1951), 187-188, 285.

18 The substandard term "rasseiskaia" is used here. This choice of word suggests pseudo-national pride. I have rendered it as "Russkie" to capture the ironic quality of the term.

${ }^{19}$ SSSR na stroike, 1930 , no. $1,3$.

20 Svetopis', a word that was not in common usage in 1930 , is comparable to the English "heliography," an archaic term for photography that literally means "sun drawing." The use of this term evokes the early years of photography, when it was accepted as an utterly objective, unmediated form of representation of external reality, a mirror of nature.

${ }^{21}$ The film attracted much attention and was extensively reviewed in the German press around the time of SSSR na stroike's initial publication. Early in 1930, Turin appeared 


\section{Left History 6.2}

at film screenings in Berlin, Hamburg, London, and Vienna, and Turksib was also distributed to Denmark, Belgium, Japan, Turkey, Finland, Switzerland, United States, and Italy. GARF, fond A-144 (Komitet sodeistviia stroitel'stvu Turkestano-Siberskoi zheleznoi dorogi pri narodnykh komisarrov RSFSR), op. 1, d. 170, 11. 26-30; GARF, fond 5283 (Vsesiouznoe obshchestvo kul'turnoi sviazei s zagranitsei), op. 1, d. 143, 11. 18-21.

${ }^{22}$ Gor'kii, "Zamechaniia po zhurnaly 'Stroika'," 1929, M. Gor'kii i sovetskaia pechat', book 1, 296.

${ }^{23}$ Gor'kii to Khalatov, end of November to 16 December 1929, M. Gor'kii $i$ sovetskaia pechat', book 1, 178.

${ }^{24}$ Khalatov to Gor'kii, 5 January 1930, M. Gor 'kii i sovetskaia pechat', book 1, 186.

${ }^{25}$ During 1930 the combined print-run of all editions was roughly 60,000 copies per issue. The size of the print-run is printed in each Russian issue and in the foreign editions from 1931, no. 12 to 1934, no. 11. By May 1930, the demand for SSSR na stroike surpassed Gosizdat's ability to print it, and subscriptions to the Russian edition were closed at 50,000. Khalatov to Gor'kii, 16 May 1930, M. Gor'kii i sovetskaia pechat', book 1, 198.

${ }^{26}$ In 1930 magazine orders from VOKS to the periodical sector of Gosizdat specified which edition. GARF, f. 5283, op. 2, d. 63, 11. 43, 51, 70, 86. By 1932 VOKS invoices no longer distinguished luxury and economy editions; this suggests that the luxury foreign versions were only published for a year or two. GARF, f. 5283, op. 2, d. 105, 11. 49-56.

${ }^{27}$ Khalatov to N. Petrov, Chairman, VOKS, 4 or 7 May 1930. GARF, f. 5283, op. 2, d. $63,1.93$.

${ }^{28}$ Khalatov to Petrov, May 1930. GARF, f. 5283, op. 2, d. 63, 1. 93.

29 For statistics and a contemporary discussion of Soviet exports and imports, see Economic Handbook of the Soviet Union (New York 1931).

30 "Soviet Products on the American Market: An Analysis of Soviet-American Trade," Economic Review of the Soviet Union 5.22-23, 448.

${ }^{31}$ For a discussion of these allegations and their effect on Soviet-American Trade, see Katherine A.S. Siegel, Loans and Legitimacy: The Evolution of Soviet-American Relations, 1919-1933 (Lexington 1996), 133-138.

${ }^{32}$ GARF, f. 5283, op. 12 , d. $318,1.84$.

${ }^{33}$ GARF, f. 5283, op. 2, d. 63, 11. 93-102.

34 Antony C. Sutton, Western Technology and Soviet Economic Development, 19171930 (Stanford 1968), 277, 290.

35 James K. Libbey, "The American-Russian Chamber of Commerce," Diplomatic History 9.3 (Summer 1985), 233, 238.

36 "Personnel of Business Men's Delegation to U.S.S.R.," Economic Review of the Soviet Union 4.12-13 (1 July 1929), 236.

${ }^{37}$ Sutton, 246-249.

38 "Percival Farquhar," The National Cyclopedia of American Biography, vol. 45 (New York 1962), 303-304.

${ }^{39}$ GARF, f. 5283 , op. 2 , d. $63,1.98$.

${ }^{40}$ GARF, f. 5283, op. 2, d. 63, 1. 95 .

${ }^{41}$ Gor'kii to Khalatov, 22 May 1930, M. Gor'kii $i$ sovetskaia pechat', book 1, 200.

42 GARF, f. 5283, op. 2, d. $63,1.95$. 
43 GARF, f. 5283, op. 2, d. 63, 1. 95.

44 GARF, f. 5283, op. 2, d. 63, 1. 97.

45 GARF, f. 5283, op. 2, d. 63, 1. 100.

${ }^{46}$ Andrew Williams, Trading with the Bolsheviks: the politics of East-West trade, 19201939 (Manchester c. 1992), 55.

47 "Parliamentary Debate on Relations with Russia: Points from Speeches," BritishRussian Gazette and Trade Outlook 6.2 (November 1929), 26-28.

${ }^{48}$ Michael Stenton and Stephen Lees, Who's Who of British Parliament, vol. 3 (Sussex 1979), 388.

49 "The Second British-Russian Gazette Luncheon," British-Russian Gazette and Trade Outlook 6.2 (November 1929), 31.

50 GARF, f. 5283, op. 2, d. 63, 1. 98 .

51 Khalatov to Petrov, 4 or 7 May 1930. GARF, f. 5283, op. 2, d. 63, 1. 93.

52 GARF, f. 5283, op. 12, d. 318, 1. 84.

53 GARF, f. 5283, op. 2, d. 63, 11. 27, 31 .

54 GARF, f. 5283, op. 2, d. 63, 1. 44, 54, 55.

55 GARF, f. 5283 , op. 12 , d. $318,1.8$.

56 In October 1930 the Central European Sector of VOKS in Moscow informed their representative in Vienna that they were unable to send more than one complimentary copy of the magazine to representatives. GARF, f. 5283, op. 2, d. 63, 1. 49.

57 GARF, f. 5283 , op. 2, d. 106, 1.83.

${ }^{58}$ A. V. Hill to VOKS, 7 October 1931. GARF, f. 5283, op. 2, d. 106, 1. 78.

${ }^{59}$ George Strauss to VOKS, 16 December 1931. GARF, f. 5283, op. 2, d. 106, 1. 70.

${ }^{60}$ Aneurin Bevan, E.J. Strachey, and George Strauss, What We Saw in Russia (London 1931).

61 George A. Cornish to VOKS, 17 October 1931. GARF, f. 5283, op. 2, d. 106, 1. 73.

62 GARF, f. 5283, op. 2, d. 63, 11. 30, 32. Susan Kingsbury, Factory, Family and Women in the Soviet Union (New York 1935).

${ }^{63}$ Dewey visited the Soviet Union with a group of American educators in 1928 and published a favorable account of his experiences. "Dewey, John," The National Cyclopedia of American Biography, vol. 40 (New York 1955), 1-2.

64 George S. Counts to B. Minlos, VOKS, 22 December 1930, GARF, f. 5283, op. 2, d. 106, 1. 107. Counts visited Russia in 1927 and 1929 and wrote extensively on the Soviet Union. "Counts, George Sylvester," The National Cyclopedia of American Biography, vol. F (New York 1942), 190.

65 Lena Madesin Phillips to Helen Schlossberg, VOKS, 21 October 1931. GARF, f. 5283, op. 2, d. $106,1.72$.

${ }^{66}$ Lisa Sergio, A Measure Filled: the Life of Lena Madesin Phillips drawn from her autobiography (New York-Washington 1972), 5, 91-92.

${ }^{67}$ Clarence Pickett to Helen Schlossberg, VOKS, 15 October 1931. GARF, f. 5283, op.

2, d. 106, 1. 79. Clarence Pickett, For More Than Bread (Boston 1953).

${ }^{68}$ GARF, f. 5283, op. 2, d. 63, 11. 80-81.

${ }^{69}$ GARF f. 5283, op. 2, d. 63, 1. 102.

${ }^{70}$ GARF f. 5283 , op. 2 , d. $63,1.99$.

${ }^{71} \mathrm{M}$. Iushkevich (1st Secretary of the Plenipotentiary of the USSR and Representative of VOKS in Poland) to Podol'sky (Otdel Pechati NKID), 3 August 1931. GARF, f. 5283, op. 2, d. 106, 1. 82 . 


\section{Left History 6.2}

72 GARF, f. 5283 , op. 2 , d. $63,1.102$.

${ }^{73}$ Rossiiskii tsentr khraneniia $\mathrm{i}$ izucheniia dokumentov noveishei istorii (RTsKhIDNI), fond 495 (Ispolnitel'nyi komitet Kominterna), op. 99, d. 35, 11. 118-120, 124-125.

${ }^{74}$ Lopez Cardozo to Editors of SSSR na stroike, 4 December 1930. GARF, f. 5283, op. 5 , d. $239,1.28$.

${ }^{75}$ The text reads "XVI-mu parts'ezdu, vozhdiu proletariata — privet!" SSSR na stroike, 1930, no. 5-6.

${ }^{76}$ Khalatov to Gor'kii, 3 February 1932 M. Gor'kii i sovetskaia pechat', book 1, 262.

77 "Khudozhestvennaia dokumentatsiia chetyrekh pobed," Literaturnaia gazeta, no. 12 1934.

78 During the course of the decade, Russian annual subscription prices steadily increased from ten to 42 rubles, while the English edition dropped from five dollars to three dollars. See appendix C for statistics on the subscription costs.

79 "Khudozhestvennaia dokumentatsiia chetyrekh pobed," Literaturnaia gazeta, no. 12 1934,4 . Sergei Tret'iakov, “Kak my delali 'Chetyre pobedy'," Literaturnaia gazeta, no. 13 1934: 4. This issue was the result of collaboration between Tret'iakov, Lissitzky, Sofia Lissitzky-Küppers, and the cameraman Eduard Tisse.

80 David King, who has a copy of the "Voroshilov edition" in his collection, provided me with details about it in telephone conversations in July and August 1997.

81 "Sovetskaia Gruziia v fotografiiakh," Pravda, 10 July 1936. "Schastlivaia Sovetskaia Gruziia!" Za industrializatsiia, 3 July 1936. Neither review mentions El Lissitzky.

${ }^{82}$ Khalatov to Gor'kii, 2 April 1933, M. Gor'kii i sovetskaia pechat', book 1, 282. The editor's apprehension over the use of photomontage is probably a reflection of debates concerning the use of photomontage in Soviet posters that took place in 1931 and 1932. For a discussion of this debate, see Hubertus Gassner, "Heartfield's Moscow Apprenticeship, 1931-1932," John Heartfield, Peter Pachnicke and Klaus Honnef, eds (New York, 1992), 256-289.

83 Sheila Fitzpatrick, "Stalin and the Making of a New Elite," The Cultural Front: Power and Culture in Revolutionary Russia (Ithaca 1992), 149-182; Fitzpatrick, "The Russian Revolution and Social Mobility: A Re-examination of the Question of Social Support for the Soviet Regime in the 1920s and 1930s," Politics and Society, 13.2 (1984), 119-142.

84 While I have not found a reference to Shaw's receipt of a subscription, Gor'kii did write to Khalatov in 1931 to request complimentary copies for the writers John Galsworthy, Romaine Rolland, and H.G. Wells. Gor'kii to Khalatov, end of January 1931, M. Gor 'kii i sovetskaia pechat', book 1, 239.

${ }^{85}$ Torsten Palmér, Jan Myrdal, and Olle Stenholm, Stalins Fotografer: Pressebilden som vapen under den första femårsplanen, 1929-1932 (Stockholm 1982). 